\title{
Anthós
}

$6-21-2021$

\section{The State of Renewable Energy in Colombia}

Magwyer Grimes

Portland State University

Follow this and additional works at: https://pdxscholar.library.pdx.edu/anthos

Part of the Latin American Studies Commons, and the Regional Economics Commons Let us know how access to this document benefits you.

\section{Recommended Citation}

Grimes, Magwyer (2021) "The State of Renewable Energy in Colombia," Anthós: Vol. 10: Iss. 1, Article 5. https://doi.org/10.15760/anthos.2021.10.1.5 


\title{
The State of Renewable Energy in Colombia
}

\author{
Magwyer Grimes
}

\section{Introduction}

Colombia is a country in the northern Andean region of South America, bordered by Venezuela to the East, Ecuador \& Peru to the Southwest, and Brazil to the South. Colombia is rich with natural resources and has many advantageous geographical features. Historically, Colombia has had a violent past with a decades long civil war among left-wing guerrillas, paramilitary groups, and the state just recently coming to a close with a historic peace deal in 2016. Now, with a burgeoning middle class and increasing global economic competitiveness, world leaders and world institutions are waking up to the vast potential Colombia possesses to lead Latin America in the coming century. Still, many unique challenges remain.

In this report, I will be exploring the energy system in Colombia, the currently installed renewable energy capacity, the benefits and drawbacks of hydroelectric energy, the hidden social and environmental costs of energy, as well as recommendations for industry and policy makers to foster resilience in the energy sector as well as ensure Colombia's continued prosperity.

\section{The Current Energy System}

Colombia is endowed with abundant natural coal deposits and vast hydroelectric potential. Its supply of crude oil is much more conservative, especially compared to Venezuela and its reserves of natural gas are moderate, but new technologies are unlocking larger and harder-to-reach deposits.

Colombia also benefits from some of the best conditions for wind power in all of Latin America, specifically in the northern region of La Guajira. In fact, multiple studies have demonstrated Colombia's wind power potential is sufficient enough to provide the entire country's electricity needs although wind power developments remain in the early stages (Norton Rose Fulbright, 2017).

Colombia's energy sector was reformed from top to bottom in the 1990s. What was a fully-integrated state-owned enterprise was broken up into four stages: generation, transmission, distribution and commercialization and each stage was then broken up and privatized into multiple companies. Vertical integration was strictly forbidden and the Comisión de Regulación de Energía y Gas (CREG) was created to determine price caps on electricity. The 1994 reform introduced market competition and has widely been considered as a success in providing consistent, low-cost electricity to Colombian consumers (Pombo \& Taborda, 2005). 
The current installed energy capacity in Colombia is demonstrated in the chart below, taken from the global law firm Norton Rose Fulbright, using data from the International Energy Agency. Hydropower constitutes the vast majority of installed capacity at $68 \%$, although the Colombian government does not qualify all hydropower as renewable. ${ }^{1}$ Hydropower is followed by natural gas at $18 \%$ and coal at $10 \%$. Biofuels represent an admirable $3 \%$ of Colombian energy generation and also represent a considerable opportunity for growth. Colombia has large agricultural export industries and organic waste occurring in the production of bananas, coffee and sugarcane create opportunities for growth in biofuels (Haubensak, 2011).

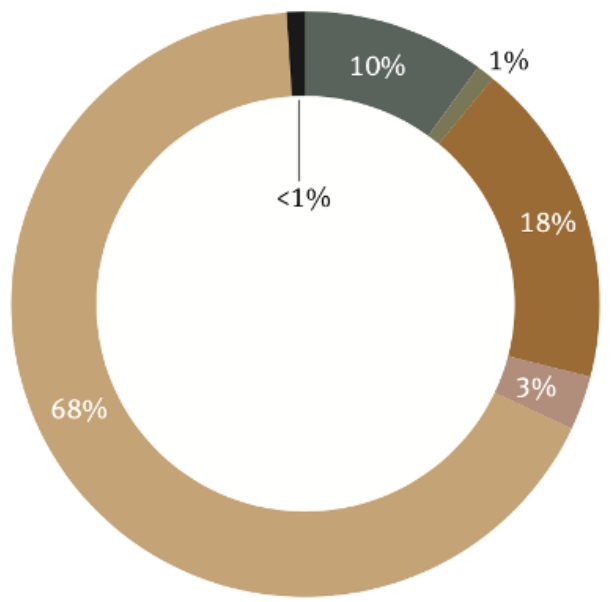

\begin{tabular}{|c|c|c|c|}
\hline \multicolumn{4}{|c|}{ Energy generation by type in Colombia } \\
\hline Coal & Gas & Biofuels & Nuclear \\
\hline Hydro & Geothermal & Solar PV & Solar Thermal \\
\hline Wind & \multicolumn{3}{|c|}{ Tide $\square$ Other sources } \\
\hline
\end{tabular}

\footnotetext{
${ }^{1}$ See “The Hydropower Question” section for more information.
} 


\section{The Hydropower Question}

By some metrics, Colombia already finds itself in an enviable position, with hydropower constituting a staggering $70 \%$ of Colombia's installed energy capacity (Caspary, 2009). But the Colombian government's own objectives only target achieving $6.5 \%$ of energy coming from renewables by 2020 . This is due to the fact that the Colombian government only classifies small hydropower plants, generating $10 \mathrm{MW}$ or less, as renewable energy. Why is that?

It is a debate currently raging within sustainability circles, but it speaks to the high environmental costs levied by large hydropower projects. On the one hand, hydropower technologies are extremely efficient at capturing energy: A hydropower plant will capture $90 \%$ of potential energy while a similarly-sized fossil fuel plant will only capture $50 \%$, at most. On the other hand, large hydropower projects can catastrophically disrupt fish migration (to the point of extinction), displace entire communities of people (most notably those without significant political power), and change the topography of a region significantly.

Even more, recent research has unveiled high levels of greenhouse gas emissions associated with both the construction of hydropower projects and the decomposition of organic matter as a result of stagnant water that otherwise would have been in constant motion. That said, not all hydropower projects are created equal; run-of-river hydroelectric projects (ROR) do not store water and therefore do not materially alter the course of a river. This ensures a much smaller environmental impact (McEntee, 2018).

Further research is needed to clarify to what extent do large hydropower projects continue to release greenhouse gases, but consensus has largely been reached in the international community that large hydroelectric projects are, at the very least, not the ideal renewable energy to focus on. Still, technological advancements that increase the efficiency of existing dams are desirable.

It is for all of the reasons listed above that Colombian government does not consider large hydro projects renewable. However, long-run economic costs still favor large-scale hydro projects but the best sites for such generation have already been exploited, meaning that future expansion depends on finding suitable sites and technological improvement (Caspary, 2009).

\section{The Hidden Cost of Externalities}

Simple cost-benefit analyses are relevant in most energy decisions, but even more so when discussing energy in Colombia. This is for two reasons: (1) Colombia has a highly privatized energy system so pricing and cost-benefit analysis is how decisions are made and (2) that Colombia's privatized system has 
been highly efficient at delivering low-cost, stable electricity so it is not likely to be subject to changing political landscapes. ${ }^{2}$

But what are externalities and why does this section's title suggest that they are hidden? In economics, externalities are simply costs (of a process, of a production, of a product, etc.) that are shifted from one entity to another. For the purposes of this report, hidden externalities are quite simply the effects that are caused by the production of energy that are not taken into account when calculating the price of these energies.

In this paper, I argue that the price of these externalities inadvertently subsidizes the production of energy from fossil fuels, thus hindering the transition to renewable energy. Examples of these hidden costs can range from the very direct, such as an injured worker, to indirect such as the contamination of local water sources. These side-effects of fossil fuel production all carry an economic cost that aren't borne by the producers and thus shifted onto local communities. To give a clearer image of the impacts of these hidden costs, we will look at one particular case study in the north of Colombia.

\section{Effects of Coal Mining in Cesar, Colombia}

In 2019 , coal was used to generate $40 \%$ of the world's electricity (International Energy Agency, 2019). In Colombia, that figure is just 10\%, but as world aggregate demand for energy continues to grow, coal as an export industry in Colombia has grown as well. In fact, Colombia accounted for a staggering 90.7\% of total coal production in Latin America in 2015 (Inestroza, 2015). The growth in the coal industry's activities have been encouraged by favorable commodity prices and policies favoring coal extraction from the national government. Necessarily, the industrial activities in coal producing regions also grew. One of those regions is Cesar, Colombia.

\footnotetext{
2 These two observations are not advanced commentary on the comprehensive results of privatization, but rather a situational summary based on the large consensus of Colombian scholars.
} 


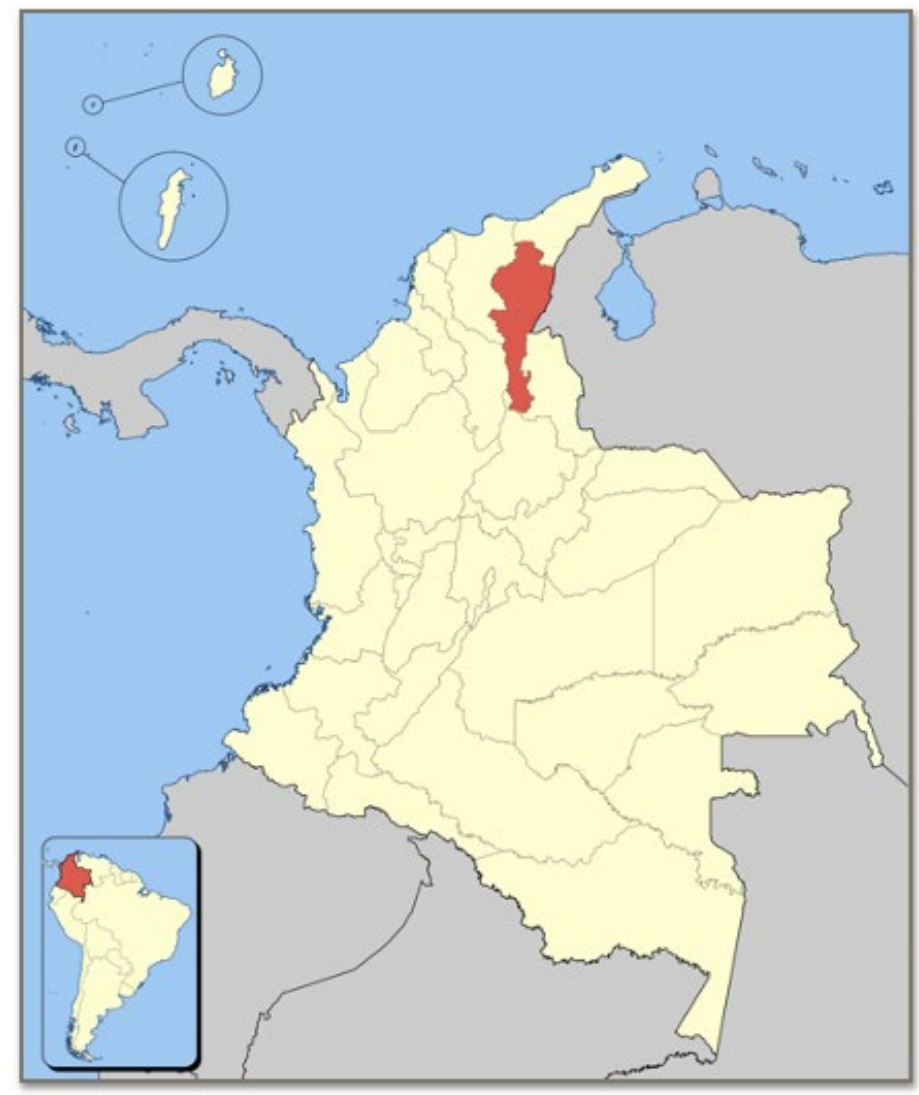

Department of Cesar. (Wikipedia Commons)

In Cesar, coal production increased $74 \%$ from 2000 to 2012 resulting in significant social and environmental implications (Cardoso, 2015). One of these implications is toxic air pollution. A study from the Universidad Nacional de Colombia demonstrated trace concentrations of mercury, arsenic, selenium, cadmium, and lead in the air (Morales \& Carmona, 2007). All are chemicals known to be related to the extraction of coal. Even more, it has been found that the level of pollutants in the drinking water in Cesar exceeds both Colombian and international standards (Cardoso, 2015). The pollution of air and water has real environmental and health repercussions for these communities that include, but are not limited to increased respiratory illnesses, cancer, impotence, ischemic heart disease, diarrhea, and stunted growth (World Health Organization, 2014). And that is not even to mention the costs that stem from lost productivity or the pain of seeing a loved one suffer from a preventable illness. 
A study done in Ecological Economics in 2015 attempted to quantify the hidden costs of externalities in the production of coal in Cesar and concluded that "unpaid damages are larger than the price of coal" (Cardoso, 2015, p. 73). To summarize and demonstrate their findings, I have compiled their data in the table below:

\begin{tabular}{|c|c|c|c|}
\hline Externalities & $\begin{array}{l}\text { Social \& } \\
\text { environmental } \\
\text { problems }\end{array}$ & $\begin{array}{l}\text { Estimate of cost } \\
\text { (2012 US\$/t of coal) }\end{array}$ & $\begin{array}{l}\text { Limitations of } \\
\text { methodology }\end{array}$ \\
\hline Air Pollution & $\begin{array}{l}\text { Surpassed permitted } \\
\text { levels of certain } \\
\text { pollutants }\end{array}$ & $0.23-7.31$ & Overestimated \\
\hline Soil Pollution & Mining waste & $39.78-59.61$ & Underestimated \\
\hline Water Pollution & $\begin{array}{l}\text { Unfit for human } \\
\text { consumption (water } \\
\text { quality index) }\end{array}$ & $0.38-0.50$ & Underestimated \\
\hline $\begin{array}{l}\text { Loss of agricultural } \\
\text { land \& livestock }\end{array}$ & $\begin{array}{l}36 \% \text { decrease in } \\
\text { temporary crops }\end{array}$ & $1.82-6.50$ & Overestimated \\
\hline Relocation & $\begin{array}{l}912 \text { families should be } \\
\text { made to relocate }\end{array}$ & $0.58-1.02$ & Underestimated \\
\hline Public health loss & $\begin{array}{l}\text { Extra mortality and } \\
\text { morbidity }\end{array}$ & $42.72-52.13$ & Underestimated \\
\hline $\begin{array}{l}\text { Total Local } \\
\text { Externalities Cost }\end{array}$ & & $85.51-127.07$ & \\
\hline
\end{tabular}

Data taken from Cardoso, Ecological Economics, 2015.

As this table demonstrates, even a conservative estimate of the local cost of externalities in Cesar is $\$ 85.51$ per ton of coal. Compare that to the price of one ton of bituminous coal in the United States in 2020 of $\$ 58.93$ and it is easy to see that the affordability of coal depends upon ignoring the associated social and environmental costs (U.S. Energy Information Agency, 2020). Several things must be mentioned, however: First, the study in the Ecological Economics journal 
was done in 2012 US dollars while the price of bituminous coal in the U.S. is in 2019 US dollars. Second, I included the cost of local externalities in the table, but the author of the study goes on to count additional national and global externalities. That is to say, my estimate is the most conservative one and it is likely that the social and environmental costs of coal surpasses the wholesale price of coal by far more than the numbers I have given.

\section{Relevance to other Energies}

The case study in Cesar, Colombia is critical to highlighting the hidden costs of coal production. That said, the tragic social and environmental costs of coal have long been established and it is important to investigate whether these numbers are relevant to other renewable and traditional energies. A study done in the journal Energy Economics titled, "Gauging the future competitiveness of renewable energy in Colombia" attempts to estimate the long-run average costs of renewable energies compared to traditional energy (Caspary, 2009). The study uses data envelopment analysis (DEA) to model the production technology frontiers of the various energy sources to project the long-run average costs in varying scenarios. Most importantly, they model the long-run average costs without taking into account global and local externalities (so business-as-usual) and then model the long-run average costs while taking into account these externalities, such as in our case study. The study done by Caspary (2009) concludes, as most studies, that further research needs to be done, but that if global and local externalities are factored into account:

The economic signal will favor a low carbon intense expansion path for the Colombia electricity sector. The magnitude of the global externality economic signal for renewable sources has a lower bound of $\$ 8.25 / \mathrm{MWh}$, or $23.5 \%$ of the estimated long run marginal cost. (pp. 447-448)

This is to say that renewable energies as a whole would enjoy a roughly $23.5 \%$ favorable shift in long-run average cost compared to traditional energies, according to their most conservative estimates, if externalities were taken into account. Another important projection includes a negative forecast for solar PV \& biomass technologies and a positive forecast for large and small-scale hydroelectric projects. ${ }^{3}$ Interestingly, the study notes that the increasing competitiveness of renewable energies occurs regardless of factoring in the cost

\footnotetext{
3 The conclusion of the study notes the importance of feasible sites specifically for hydroelectric $\&$ biomass projects.
} 
of externalities, but that further policies supporting renewable energy development could accelerate the process.

\section{Conclusion}

Colombia currently is able to enjoy bountiful opportunities in its energy sector owing to its rich natural resource endowment and highly efficient private energy sector. Even more, my report has demonstrated that renewable's long-run average costs will continue to improve even if policymakers in Colombia don't make any significant changes to their energy sector. However, that is not an excuse to do nothing and, in fact, doing nothing would ignore the lucrative opportunities that renewable energies offer:

First, renewable energies are free. That is a simplification, of course, because you need to first construct the wind turbines, the geothermal facilities, the biomass processors, and the solar panels need to be bought and installed. Still, it does not take any complicated economic analysis to realize that the wind will keep on blowing and the sun will keep on shining regardless of whether or not we choose to take advantage of Earth's boundless streams of free energy. This stands in stark contrast to the high costs of the extractive fossil fuel energies whose costs not only are evident in the degradation of the land, but also in the poorer community health outcomes that has become an emblem of extractive industries. ${ }^{4}$

Second, renewable energies have greater ability to reach more remote, usually more rural communities. This is evidenced by the Colombian government's own objective targeting $30 \%$ of energy flowing in 'remote areas' to be coming from renewables by 2020 while their corresponding objective is only $6.5 \%$ for the nation as a whole (Haubensak, 2011).

Third, extractive industries in Colombia are largely export industries and largely owned by foreign companies. In Cesar, the three main companies who have exported $70 \%$ of the total coal production are Drummond, Prodeco, and Colombian Natural Resources which are all directly or indirectly owned by American or Swiss multinational corporations (Cardoso, 2015). Foreign-owned companies, by their very nature, attempt to extract as much value as possible back to their respective financial centers while contributing the least to the value chains from where the wealth is taken. It is therefore a questionable premise from the start to allow heavy industry to be foreign-owned without a corresponding set of regulations that ensures value-sharing and community involvement. Renewables hold the opportunity for Colombian energy companies to be domestically or even locally-owned which halts the degradation of the land and raises local incomes.

\footnotetext{
${ }^{4}$ See "The Hidden Cost of Externalities" section for more information.
} 
In this report, I attempted to give an insightful summary of the Colombian energy system as well as some of the unique questions and conditions that define it. In particular focus was the ongoing debate around large hydroelectric projects and the hidden cost of externalities of fossil fuel extraction. This production, I believe, is subsidized by the worsened health outcomes and environmental degradation and slows the transition to a renewable energy system. In fact, it could be argued that it is this distortion of the free market that has enabled fossil fuels to remain globally competitive. That said, long-run average costs remain constantly shifting in favor of renewable energies despite the profuse subsidies that the fossil fuel industry continues to receive.

\section{References}

Cardoso, A. (2015). Behind the life cycle of coal: Socio-environmental liabilities of coal mining in Cesar, Colombia. Ecological Economics, 120, 71-82.

Caspary, G. (2009). Gauging the future competitiveness of renewable energy in Colombia. Energy Economics, 31(3), 443-449.

Eitzinger, A., Läderach, P., Bunn, C., Quiroga, A., Benedikter, A., Pantoja, A., . . . Bruni, M. (2012). Implications of a changing climate on food security and smallholders' livelihoods in Bogotá, Colombia. Mitigation and Adaptation Strategies for Global Change, 19(2), 161-176.

Haubensak, O. (2011, April 11). The Future Prospects of Renewable Energy in Colombia (1052218348 803424940 T. Rutherford, Ed.). Energy Economics and Policy.

Inestroza, J. J. (2019, May). The Mineral Industry of Colombia. Retrieved November 27, 2020, from https://www.usgs.gov/media/files/mineralindustry-colombia-2015-pdf

International Energy Agency. (2019, December). Coal 2019 - Analysis. Retrieved November 27, 2020, from https://www.iea.org/reports/coal-2019

Jimenez, M., Franco, C. J., \& Dyner, I. (2016). Diffusion of renewable energy technologies: The need for policy in Colombia. Energy, 111, 818-829.

Kirk, C. (2012, June 19). Where Farmers Live and Which Countries Don't Have Enough. Retrieved November 30, 2020, from http://www.slate.com/articles/technology/future tense/2012/06/a map of farmers in the $\mathrm{u}$ s and world .html?query=Hillary+Clinton $\% 2 \mathrm{C}+$ Don ald+Trump

Morales, W., \& Carmona, I. (1970, January 01). ESTUDIO DE ALGUNOS ELEMENTOS TRAZA EN LA CUENCA CESAR - RANCHERIA, COLOMBIA. Retrieved November 27, 2020, from http://www.redalyc.org/articulo.oa?id=169513312004 
Norton Rose Fulbright. (February 2017). Renewable Energy in Latin

America: Colombia, 20-22.

Pombo, C., \& Taborda, R. (2006). Performance and efficiency in Colombia's power distribution system: Effects of the 1994 reform. Energy Economics, 28(3), 339-369.

Robertson, Margaret. 2014. Sustainability: Principles and Practice. London: Routledge Rosso-Cerón, A. M., \& Kafarov, V. (2015). Barriers to social acceptance of renewable energy systems in Colombia. Current Opinion in Chemical Engineering, 10, 103-110. U.S. Energy Information Administration - EIA - Independent Statistics and Analysis. (2020, October 9). Retrieved November 27, 2020, from https://www.eia.gov/energyexplained/coal/prices-and-outlook.php

Weise, E. (2020, February 20). Wind energy gives American farmers a new crop to sell in tough times. Retrieved November 30, 2020, from https://www.usatoday.com/story/news/nation/2020/02/16/wind-energycan-help-american-farmers-earn-money-avoid-bankruptcy/4695670002/

Windustry. (n.d.). How much do wind turbines cost? Retrieved November 30, 2020, from http://www.windustry.org/how much do wind turbines_cost

World Health Organization. (2014, March 25). 7 million premature deaths annually linked to air pollution. Retrieved November 27, 2020, from https://www.who.int/mediacentre/news/releases/2014/air-pollution/en/

Wright, A. (2019, June 17). Scientists around the world are working to turn agricultural waste into food, packaging and more. Retrieved November 30, 2020, from https://medium.com/ensia/scientists-around-the-world-areworking-to-turn-agricultural-waste-into-food-packaging-and-more$\underline{\text { fd9508de26b9 }}$ 